\title{
Long Distance Reverse-Transcription PCR
}

\author{
Volker Thiel, Jens Herold, and Stuart G. Siddell
}

\section{Introduction}

Polymerase chain reaction (PCR) has been applied to the amplification of long DNA fragments from a variety of sources, including genomic, mitochondrial, and viral DNAs (1-5). We have adapted the concept of long PCR technology to reverse-transcription (RT) PCR (6). Here, we describe the parameters critical in producing RT-PCR products of up to $20 \mathrm{kbp}$. The nature of RT-PCR requires the synthesis of a cDNA by RT prior to its amplification in the PCR reaction. Thus, we focus on the three steps of RT-PCR: the preparation and requirements of the RNA template, the reverse transcription reaction, and the amplification of the cDNA by PCR.

To carry out these studies, we used the genomic RNA of the human coronavirus HCoV 229E as template (7). The HCoV 229E genomic RNA has a length of ca. 27,000 nucleotides and the homogeneity of the RNA can be readily assessed by electrophoresis and hybridization analysis (8). HCoV 229E genomic RNA has two major advantages for the studies reported here. First, as a viral RNA, it is relatively abundant in the infected cell. Second, coronaviruses are positive strand RNA viruses and the genomic RNA has a 3 ' polyadenylate tract that can be used for affinity chromatography (9).

In Subheading 3.1., we describe a simple and fast technique to purify poly(A)containing RNA from tissue culture cells. In fact, we believe that the integrity and purity of the RNA template is the most critical parameter when the RT-PCR amplification of sequences more than $5 \mathrm{~kb}$ in length is desired (6) (see Note 4, Fig. 1). Depending on the source of the RNA template, a method of preparation should be chosen that minimizes degradation of the RNA. In our hands oligo (dT)-based affinity chromatography with magnetic beads has proven to be reliable for the isolation of poly(A)-RNA that can be used to produce cDNA of more than $20 \mathrm{~kb}$ by RT.

The conditions of the reverse transcription reaction strongly influence the outcome of the subsequent PCR. Reverse transcription reactions have been performed using the RNase H-deficient reverse transcriptase, SuperScript II and the cDNA has been used for PCR amplification without further purification. In general, an RT-primer should

From: Methods in Molecular Biology, Vol. 192: PCR Cloning Protocols, 2nd Edition Edited by: B.-Y. Chen and H. W. Janes $\odot$ Humana Press Inc., Totowa, NJ 


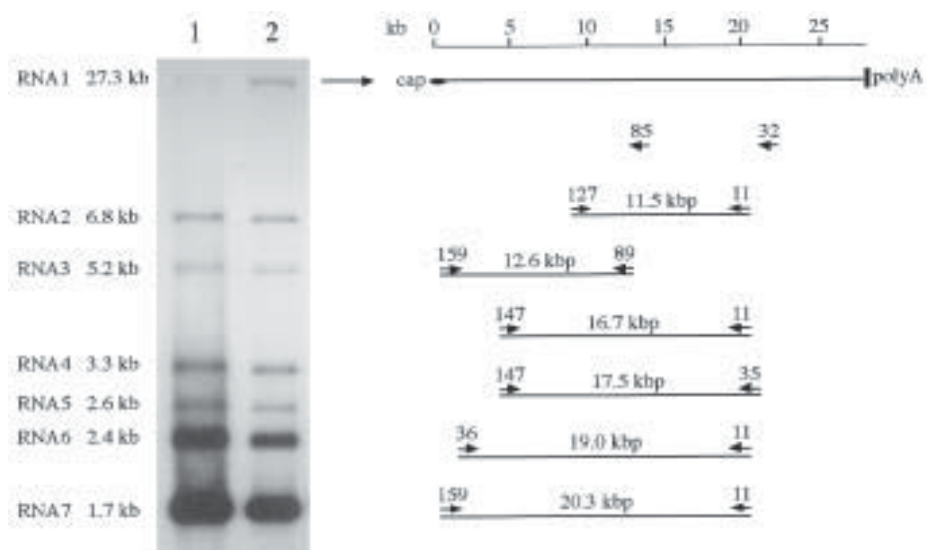

Fig. 1. Northern hybridization analysis of $\mathrm{HCoV} 229 \mathrm{E}$ poly(A)-containing RNA isolated from infected MRC-5 cells. The material shown in lane 1 was prepared using poly(U)Sepharose (6). The material shown in lane 2 was prepared using oligo $(\mathrm{dT})_{25}$ magnetic beads as described in Subheading 3.1. The poly(A)-containing RNAs were separated by gel electrophoresis and the viral mRNAs were hybridized to a ${ }^{32} \mathrm{P}$-(5'end)-labeled oligonucleotide (5'AGAAACTTCTCACGCACTGG 3'). Also shown is the relationship of the HCoV 229E genomic RNA template, oligonucleotide primers and RT-PCR products. The oligonucleotides are indicated as arrows with their orientation and position relative to the HCoV 229E genomic RNA. The expected sizes of the RT-PCR products are indicated.

be used that is highly specific and great care should be taken to adjust the optimal concentration of the RT-primer in the reverse transcription reaction. In our experience, the major problem that arises is "less stringent" priming during the RT reaction. The fortuitous cDNAs that are synthesized and the small amounts of RT-primer that are carried over into the PCR are responsible for most of the background amplification products observed (6).

Finally, the optimal conditions, regarding the amount of cDNA template, the choice of PCR primers and the cycle profile of the PCR, have to be determined. In this respect, the considerations that apply to the PCR amplification of dsDNA templates are equally applicable to amplification of cDNA produced by reverse transcription.

\section{Materials}

1. Phosphate-buffered saline (PBS).

2. Lysis buffer: $10 \mathrm{~m} M$ Tris- $\mathrm{HCl}, \mathrm{pH} 7.5,140 \mathrm{mM} \mathrm{NaCl}, 5 \mathrm{mM} \mathrm{KCl}, 1 \%$ Nonidet P-40 (NP40).

3. Oligo(dT) $)_{25}$-Dynabeads (Dynal) $\left(3.3 \times 10^{8}\right.$ beads $\left./ \mathrm{mL}\right)$.

4. Dynal Magnetic Particle Concentrator (Dynal). 
5. $2 \mathrm{X}$ binding buffer: $20 \mathrm{~m} M$ Tris- $\mathrm{HCl}, \mathrm{pH} 7.5,1 M \mathrm{LiCl}, 2 \mathrm{~m} M$ ethylenediamine tetraacetic acid (EDTA), $1 \%$ sodium dodecylsulfate (SDS).

6. Wash buffer: $10 \mathrm{~m} M$ Tris-HCl, $\mathrm{pH} 7.5,150 \mathrm{~m} M \mathrm{LiCl}, 1 \mathrm{~m} M$ EDTA, $1 \mathrm{~m} M$ EDTA pH 7.5.

7. SuperScript II reverse transcriptase (Life Technologies).

8. $5 \mathrm{X}$ first-strand buffer (Life Technologies).

9. $10 \mathrm{~m} M$ dNTPs (10 $\mathrm{m} M$ of each dNTP).

10. $0.1 M$ dithiothreitol (DTT).

11. RNasin $(50 \mathrm{U} / \mu \mathrm{L})$ (Pharmacia).

12. Thin-wall PCR tubes.

13. Elongase Enzyme Mix (Life Technologies).

14. PCR buffer B (Life Technologies).

\section{Methods}

\subsection{The RNA Template: Preparation of Poly(A)-Containing RNA Using Oligo $(d T)_{25}$-Dynabeads}

The protocol below describes the isolation of poly(A)-containing RNA from a confluent layer of adherent cells grown in a $175 \mathrm{~cm}^{2}$ tissue culture flask (see Note 1).

1. Wash $200-500 \mu \mathrm{L}$ oligo(dT) ${ }_{25}$-Dynabeads twice with $2 \mathrm{X}$ binding buffer using an appropriate Dynal Magnetic Particle Concentrator (see Note 2) and resuspend the beads in $1.5 \mathrm{~mL} 2 \mathrm{X}$ binding buffer.

2. Wash the cells twice with ice-cold PBS and then scrape in $10 \mathrm{~mL}$ ice-cold PBS.

3. Pellet the cells at $1000 \mathrm{~g}$ for $2 \mathrm{~min}$ at $4^{\circ} \mathrm{C}$.

4. Resuspend the cell pellet in $1.5 \mathrm{~mL}$ ice-cold lysis buffer and incubate for $30 \mathrm{~s}$ on ice.

5. Centrifuge the cell lysate at $1500 \mathrm{~g}$ for $1 \mathrm{~min}$ at $4^{\circ} \mathrm{C}$ to remove nuclei.

6. Mix the supernatant with oligo $(\mathrm{dT})_{25}$-Dynabeads resuspended in $1.5 \mathrm{~mL} 2 \mathrm{X}$ binding buffer (Step 1) and incubate for $5 \mathrm{~min}$ at $23^{\circ} \mathrm{C}$. Gently mix the sample every $1-2 \mathrm{~min}$.

7. Wash the oligo $(\mathrm{dT})_{25}$ magnetic beads twice with wash buffer using an appropriate Dynal Magnetic Particle Concentrator (see Note 3).

8. Completely remove the wash buffer and add 50-100 $\mu \mathrm{L} 2 \mathrm{~m} M$ EDTA, $\mathrm{pH}$ 7.5.

9. Transfer the solution into a $1.5-\mathrm{mL}$ Eppendorf tube and incubate for $2 \mathrm{~min}$ at $65^{\circ} \mathrm{C}$ to elute the bound poly(A)-RNA.

10. Take the supernatant containing the poly(A)-RNA, add $5 \mu \mathrm{L}$ RNasin and store at $-70^{\circ} \mathrm{C}$ in aliquots (see Note 4).

11. Regenerate the oligo(dT) ${ }_{25}$-Dynabeads according to the manufacturer's instructions (optional; see Note 5)

\subsection{The RT Reaction}

1. Add the following components to a volume of $19 \mu \mathrm{L}$ (see Note 6):

RNase-free water

$4 \mu \mathrm{L} 5 \mathrm{X}$ first strand buffer;

$2 \mu \mathrm{L} 10 \mathrm{~m} M$ dNTPs $(10 \mathrm{~m} M$ of each dNTP);

$2 \mu \mathrm{L} 0.1 M$ DTT;

$0.5 \mu \mathrm{L}$ RNasin $(50 \mathrm{U} / \mu \mathrm{L})$;

5-15 pmol reverse transcription primer (see Note 7);

$10-500 \mathrm{ng}$ poly(A)-RNA $(0.5-3 \mu \mathrm{L}$ of poly(A)-containing RNA prepared as described earlier). 
2. Incubate for $2 \mathrm{~min}$ at $42^{\circ} \mathrm{C}$ (see Note 8).

3. Add $1 \mu \mathrm{L}(200 \mathrm{U})$ SuperScript II reverse transcriptase.

4. Incubate for $60-90 \mathrm{~min}$ at $42^{\circ} \mathrm{C}$ (see Note 9).

5. Incubate for $2 \mathrm{~min}$ at $94^{\circ} \mathrm{C}$ and chill on ice (see Note 10 ). Store at $-20^{\circ} \mathrm{C}$ until use.

\subsection{The PCR Reaction}

To amplify long DNA fragments from cDNA templates the basic principles of long PCR technology are applicable (see Note 11). The protocol below describes a typical reaction using the Elongase Enzyme Mix (Life Technologies). In addition, we provide a list of PCR cycle profiles (Fig. 2) and corresponding oligonucleotide primers (Fig. 1, Table 1) that have been used to produce RT-PCR products of $11.5-20.3 \mathrm{kbp}$ in length.

1. Set up the PCR reaction mix in thin-wall PCR tubes on ice $[50 \mu \mathrm{L}$ volume; final concentrations: $60 \mathrm{~m} M$ Tris-SO $\mathrm{SO}_{4}(\mathrm{pH} 9.1), 18 \mathrm{~m} M\left(\mathrm{NH}_{4}\right)_{2} \mathrm{SO}_{4}, 2 \mathrm{~m} M \mathrm{MgSO}_{4}, 0.2 \mathrm{~m} M$ dNTPs, $0.2-0.4 \mu M$ PCR primer]:

$10 \mu \mathrm{L}$ buffer B (Life Technologies) (see Note 12);

$1 \mu \mathrm{L} 10 \mathrm{~m} M$ dNTPs (10 $\mathrm{m} M$ of each dNTP);

$1-2 \mu \mathrm{L}$ forward PCR primer (10-40 pmol);

$1-2 \mu \mathrm{L}$ reverse PCR primer $(10-40 \mathrm{pmol})$;

$0.2-3 \mu \mathrm{L}$ RT-reaction;

$1 \mu \mathrm{L}$ Elongase Enzyme Mix (1 U/ $\mu \mathrm{L})$;

water to a final volume of $50 \mu \mathrm{L}$;

2. Place PCR tubes in an appropriate PCR cycler at $94^{\circ} \mathrm{C}$ (see Note 13).

Cycle conditions:

$1 \mathrm{~min} 94^{\circ} \mathrm{C}$, followed by 30 cycles of $20 \mathrm{~s}$ denaturation at $94^{\circ} \mathrm{C}, 20 \mathrm{~s}$ annealing at $50^{\circ} \mathrm{C}$ and elongation for $1 \mathrm{~min} / \mathrm{kb}$ expected product length at $68^{\circ} \mathrm{C}$. Increase the elongation time during the last 18 cycles by $15-30 \mathrm{~s}$ in each successive cycle. Incubate additional $10 \mathrm{~min}$ at $72^{\circ} \mathrm{C}$ and terminate the reaction by decreasing the temperature to $4^{\circ} \mathrm{C}$.

\section{Notes}

1. The number of cells will be about $10^{7}-10^{8}$ depending on the tissue culture cell line used. We recommend preparing the RNA from a confluent cell layer using at least one $175 \mathrm{~cm}^{2}$ tissue culture flask. This ensures that you will get enough poly(A)-containing RNA to perform several RT reactions using the same RNA preparation.

2. There are different Magnetic Particle Concentrators recommended, depending on the size of the tubes. To lyse the cells and bind the RNA to the oligo $(\mathrm{dT})_{25}$ magnetic beads, we use $15 \mathrm{~mL}$ tubes. Before we elute the poly(A)-containing RNA, we transfer the oligo(dT) ${ }_{25}$ magnetic beads into a $1.5-\mathrm{mL}$ Eppendorf tube.

3. If the oligo(dT $)_{25}$ magnetic beads appear to clump and do not resuspend well, you have cellular DNA in your sample. However, you can proceed without affecting the RNA quality or yield, if you perform additional washing steps (2-4) until the oligo(dT) ${ }_{25}$ magnetic beads can be resuspended easily.

4. We strongly recommend analyzing the RNA template integrity before cDNA synthesis. We routinely perform a northern hybridization analysis. In Fig. 1 poly(A)-containing RNA prepared from HCoV 229E infected MRC-5 cells using two different methods are shown. In both RNA preparations, it is possible to identify the HCoV $229 \mathrm{E}$ genomic RNA $(27.3 \mathrm{~kb})$ and the six subgenomic mRNAs $(1.7 \mathrm{~kb}-6.8 \mathrm{~kb})$ that are characteristic of 


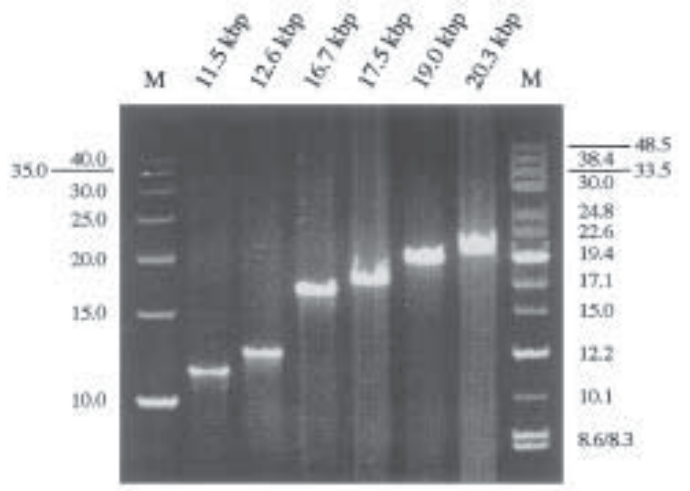

\begin{tabular}{|c|c|c|}
\hline RT-PCR product & & CR cycle profile \\
\hline $\begin{array}{l}11.5 \mathrm{kbp} \\
12.6 \mathrm{kbp}\end{array}$ & $\begin{array}{l}12 x \\
16 x\end{array}$ & $\begin{array}{l}94^{\circ} \mathrm{C} \text { Imin } \\
94^{\circ} \mathrm{C} 30 \mathrm{sec} \\
50^{\circ} \mathrm{C} 30 \mathrm{sec} \\
68^{\circ} \mathrm{C} 10 \mathrm{~min} \\
94^{\circ} \mathrm{C} \text { 30sec } \\
50^{\circ} \mathrm{C} 30 \mathrm{sec} \\
68^{\circ} \mathrm{C} 10 \mathrm{~min}(+15 \text { sec per cycle }) \\
68^{\circ} \mathrm{C} 10 \mathrm{~min}\end{array}$ \\
\hline $\begin{array}{l}16,7 \mathrm{kbp}, \\
17.5 \mathrm{kbp}\end{array}$ & $\begin{array}{l}12 x \\
16 x\end{array}$ & 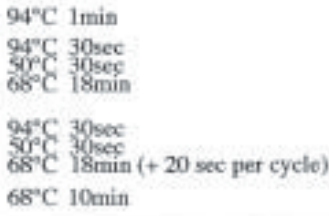 \\
\hline $\begin{array}{l}19.0 \mathrm{kbp} \\
20.3 \mathrm{kbp}\end{array}$ & $\begin{array}{r}5 x \\
25 x\end{array}$ & $\begin{array}{l}94^{\circ} \mathrm{C} \text { Imin } \\
94^{\circ} \mathrm{C} \text { soc } \\
50^{\circ} \mathrm{C} \text { 20sec } \\
66^{\circ} \mathrm{C} 23 \mathrm{~min} \\
94^{\circ} \mathrm{C} \text { 30sec } \\
68^{\circ} \mathrm{C} 23 \mathrm{~min}(+30 \text { sec per cycle }) \\
68^{\circ} \mathrm{C} \text { 10 min }\end{array}$ \\
\hline
\end{tabular}

Fig. 2. Pulse-field gel electrophoresis of HCoV 229E RT-PCR products. Five microliters of each PCR reaction were separated by PFGE together with a 5-kbp DNA ladder and a highmolecular weight DNA marker (Life Technologies). Also shown are the cycle profiles that have been used to produce RT-PCR products ranging from 11.5-20.3 kbp in length. 


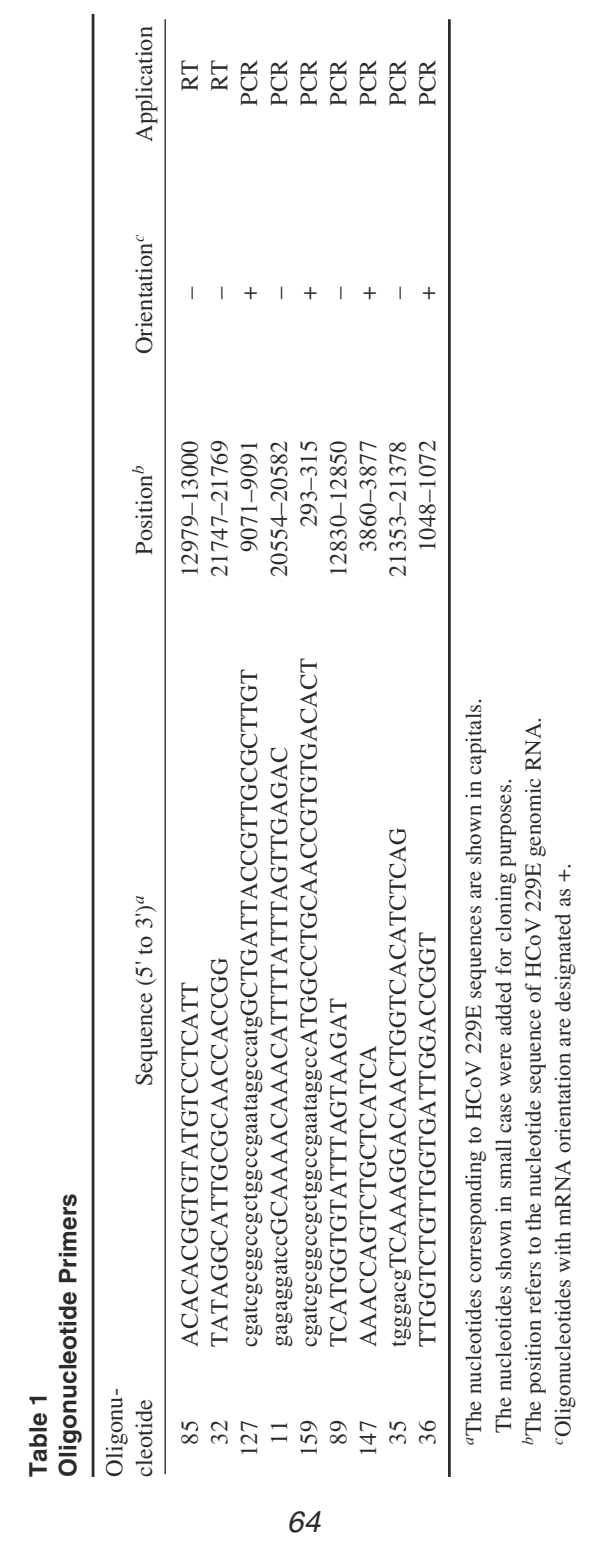


coronavirus infection. The hybridization analysis indicates that the material prepared using the oligo $(\mathrm{dT})_{25}$ magnetic beads (lane 2 ) is less degraded than the material prepared using poly(U)-Sepharose (lane 1). RT-PCR amplifications of more than $5 \mathrm{kbp}$ were only possible when poly(A)-containing RNA shown in lane 2 was used as the template for reverse transcription.

5. The oligo $(\mathrm{dT})_{25}$ magnetic beads can be regenerated according to the manufacturer's instructions (Dynal). However, during the repeated washing steps, you will loose about $20 \%$ of the magnetic beads.

6. Add the reagents in the order listed in Subheading 3.2. To melt RNA structures before the reverse transcription, some protocols recommend to heat the RNA for $10 \mathrm{~min}$ at $70^{\circ} \mathrm{C}$. However, in most cases this is not necessary.

7. Because the RT is performed at $42^{\circ} \mathrm{C}$, cDNAs can be generated during the RT reaction by "less stringent" priming events. This is the reason for most of the background PCR products observed in our system. Therefore, it is absolutely necessary to use a highly specific RT-primer and to adjust the optimal primer concentration in the RT-reaction (6). Furthermore, we recommend the use of different primers for the RT and PCR reactions.

8. Before adding the SuperScript II enzyme, the RNA template and the RT-primer should be at $42^{\circ} \mathrm{C}$ to minimize unspecific binding.

9. We recommend incubation for $90 \mathrm{~min}$ when cDNA synthesis of more than $10 \mathrm{~kb}$ is desired. Increasing the incubation temperature above $42^{\circ} \mathrm{C}$ was not beneficial in our hands.

10. Some protocols for the amplification of long mRNAs have required digestion of the RNA with RNase H after cDNA synthesis (11). This step did not seem to be necessary for amplification with HCoV 229E genomic RNA. This may be owing to the fact that in our protocols the HCoV 229E RNA was relatively abundant. Experiments with dystrophin mRNA required treatment with RNase $\mathrm{H}$ prior to amplification (6).

11. The PCR cycle conditions have to be optimized according to the amount of template, the PCR primers and the cycle profile. We recommend that these parameters should be optimized with RT-PCRs of expected product sizes below $5 \mathrm{kbp}$ before trying to synthesize longer RT-PCR products.

12. This will result in a $\mathrm{Mg}^{2+}$ concentration of $2 \mathrm{mM}$.

13. Optional: a "real" hot start can be performed by adding the enzyme mix after the PCR sample has reached $94^{\circ} \mathrm{C}$.

\section{Acknowledgments}

The authors would like to thank A. Rashtchian for helpful discussions and providing SuperScript II reverse transcriptase and Elongase Enzyme Mix. This work was supported by a Grant (SFB 165/B1) from the German Research Council (DFG) to SGS.

\section{References}

1. Barnes, W. M. (1994) PCR amplification of up to 35-kb DNA with high fidelity and high yield from lambda bacteriophage templates. Proc. Natl. Acad. Sci. USA 91, 2216-2220.

2. Cheng, S., Fockler, C., Barnes, W. M., and Higuchi, R. (1994) Effective amplification of long targets from cloned inserts and human genomic DNA. Proc. Natl. Acad. Sci. USA 91, 5695-5699.

3. Cheng, S., Chang, S.Y., Gravitt, P., and Respess, R. (1994) Long PCR. Nature 369, 684-685.

4. Cheng, S., Higuchi, R., and Stoneking, M. (1994) Complete mitochondrial genome amplification. Nature Genet. 7, 350-351. 
5. Cheng, S., Chen, Y., Monforte, J. A., Higuchi, R., and Van Houten, B. (1995) Template integrity is essential for PCR amplification of 20- to $30-\mathrm{kb}$ sequences from genomic DNA. PCR Meth. Appl. 4, 294-298.

6. Thiel, V., Rashtchian, A., Herold, J., Schuster, D. M., Guan, N., and Siddell, S. G. (1997) Effective amplification of 20-kb DNA by reverse transcription PCR. Analyt. Biochem. 252, 62-70.

7. Herold, J., Raabe, T., and Siddell, S. (1993) Molecular analysis of the human coronavirus (strain 229E) genome. Arch.Virol. [Suppl] 7, 63-74.

8. Raabe, T., Schelle-Prinz, B., and Siddell, S. G. (1990) Nucleotide sequence of the gene encoding the spike glycoprotein of human coronavirus HCV 229E. J. Gen. Virol. 71, 1065-1073.

9. Siddell, S. (1983) Coronavirus JHM: coding assignments of subgenomic mRNAs. J. Gen.Virol. 64, 113-125.

10. Ausubel, F. M., Brent, R., Kingston, R. E., Moore, D. D., Seidman, J. D., Smith, J. A., and Struhl, K. (1987) Current Protocols in Molecular Biology, (Benson Chanda, V., ed.), Wiley, New York.

11. Nathan, M., Mertz, L. M., and Fox, D. K. (1995) Optimizing Long RT-PCR. Focus 17, $78-80$. 